\title{
斜方蒸着と電界印加冷却による強誘電性液晶 セルの分子配向制御
}

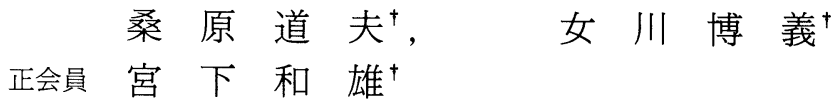

あらまし 酸化イットリウムや酸化サマリウムなどの斜方蒸着膜上で強誘電性液晶（FLC）は垂 直配向するが, 光学応答は得られない.ただし, 常誘電異方性が負で, コレステリックやスメクチ ック A 相を経てカイラル・スメクチック相に転移するFLCであれば, 冷却中に一定の電界を加え ると液晶分子が平行配向に近づくと期待される。そこで, 斜方蒸着と電界印加冷却を組合せれば, 電極外部が垂直配向を保ち光学応答を示すセルができると考えた．実験では液晶に CS-1011 を使 い, 基板には酸化イットリウムを $40^{\circ} \sim 80^{\circ}$ 蒸着した, 冷却中に最大強度 $20 \mathrm{MV} / \mathrm{m}$ の直流電界ま たは $0.1 \mathrm{~Hz} \sim 1 \mathrm{kHz}$ の対称方形波電界を加えた。さらに, 顕微鏡観察と静電容量および自発分極 の測定によって冷却中の配向変化や電界による配向効果を調べた，これらの結果，電極上の液晶分 子は最大で約 $50^{\circ}$ 傾斜し，スメクチック層が電極面に対して $40^{\circ} \sim 50^{\circ}$ まで傾いたことがわかった. また, セルの電気光学応答も得られた。

\section{1. まえ がき}

大型画面で精細度の高い液晶表示素子を目標とし て, 様々な方向から研究, 開発が進んでいる.特に, 強誘電性スメクチック液晶（FLC）については, 高速 応答 ${ }^{1)}$ と表示メモリー1 ${ }^{1)}$ 生かして, 単純マトリクス 型の電極構造をもつ大型表示素子を作ることが期待さ れている.

FLC 素子を実用化するためには, 液晶物質の合成, 表面安定化 (SS) 型の分子配向構造 ${ }^{1)}$ に必要な薄いパ ネル厚の制御 ${ }^{2)}$, 駆動方法の開発3)4 などと共に, 分子 配向の方法を確立することが重要な課題となってい る、配向制御については, 基板表面に高分子膜を付け てラビングする方法 ${ }^{56)}$ が有望だと考えられている. また, ネマチック液晶素子と同様に, 一酸化ケイ素 ( $\mathrm{SiO})$ を斜方蒸着 ${ }^{7}$ したり, 回転斜方蒸着 ${ }^{8)}$ すること も報告されている，我々は，イットリウムやサマリウ

$\dagger$ 富山大学 工学部

"Molecular Alignment Control in Ferroelectric Liquid Crystal Cells by Combined Effects of Oblique Deposition and Electric Field Application in the Cooling Process" by Michio Kuwahara, Hiroyoshi Onnagawa and Kazuo Miyashita (Department of Electronics,

Toyama University, Toyama)
ムなどの酸化物を斜方蒸着した基板によって FLC 分 子が垂直配向することを見いだした ${ }^{910)}$. しかし，こ の配向では自発分極 $\left(P_{\mathrm{S}}\right)$ が電極表面と平行になるた め, $\mathrm{P}_{\mathrm{s}}$ の反転に伴う電気光学効果は観察されなかっ

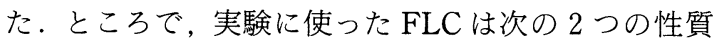
を持つものであった． (1)等方性液体 $\left(\mathrm{I}_{\mathrm{So}}\right)$ セカイラル・ ネマチック $\left(\mathrm{N}^{*}\right)$ セスメクチック $\mathrm{A}\left(\mathrm{S}_{\mathrm{A}}\right)$ セカイラル・ スメチック C $\left(\mathrm{S}_{\mathrm{c}}{ }^{*}\right)$ という相系列を持つ. (2)常誘電異 方性は負である。そこで, 液晶を注入したあと，セル に一定の電界を加えながら $\mathrm{I}_{\mathrm{so}}$ 相から $\mathrm{S}_{\mathrm{c}}{ }^{*}$ 相まで冷却 することを考えた。この配向処理方法を電界印加冷却 と呼ぶ.この処理によって $\mathrm{N}^{*}$ 相や $\mathrm{S}_{\mathrm{A}}$ 相において FLC 分子が平行配向に近づき, スメクチック層が電 極表面に対して垂直に形成されることを期待した。こ の論文では，冷却中に加えた電界によって分子配向が どのように変わったかを報告する．

\section{2. 実験}

\section{1 斜方蒸着の方法とセルの構造}

図 1 亿蒸着方法を示す. 蒸着した材料は酸化イット リウム $\left(\mathrm{Y}_{2} \mathrm{O}_{3}\right)$, 酸化サマリウム $\left(\mathrm{Sm}_{2} \mathrm{O}_{3}\right)$, 酸化アルミ ニウム $\left(\mathrm{Al}_{2} \mathrm{O}_{3}\right)$ である.これらの材料を電子ビーム加 


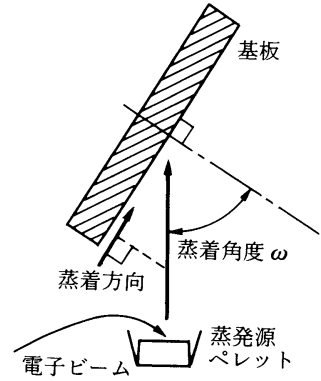

図 1 金属酸化物の斜方蒸着

Oblique deposition of metal oxide film.

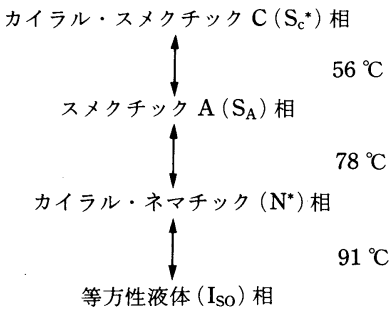

図 2 強誘電性液晶 CS-1011 の相系列 Phase sequence of the ferroelectric liquid crystal CS-1011.

\begin{tabular}{c|cc}
$\begin{array}{c}\text { 表 } 1 \text { 強誘電性液晶 CS-1011 の物性定数 } \\
\text { Material comstants of the ferro- } \\
\text { electric liquid crystal CS-1011. }\end{array}$ \\
\hline \hline 自発分極 $P_{S}$ & $\begin{array}{r}15 \mathrm{nC} / \mathrm{cm}^{2} \\
\left(26^{\circ} \mathrm{C}\right)\end{array}$ \\
\hline チルト角 $\theta$ & $22^{\circ}$ & $\left(26^{\circ} \mathrm{C}\right)$ \\
\hline らせんピッチ & $\begin{array}{l}9 \mu \mathrm{m} \\
\left(51^{\circ} \mathrm{C}\right) \\
\end{array}$ & $\begin{array}{l}5 \mu \mathrm{m} \\
\left(25^{\circ} \mathrm{C}\right)\end{array}$ \\
\hline 常誘電異方性 & 負 & \\
\hline
\end{tabular}

熱によって蒸発させ，厚さが $150 〜 200 \mathrm{~nm}$ で透明な 絶縁性の膜を基板に付けた。蒸着角度 $\omega$ は $40^{\circ}$ から $80^{\circ}$ までの範囲で実験した。また, $0^{\circ}$ 蒸着膜について も分子配向の状態を調べた，以下，蒸発物が基板に入 射した方向を基板面へ射影したもので蒸着方向を定義 する。

基板には酸化インジウム(ITO)電極をもつガラス板 を使った．セル厚 $d$ は 1.5 2.9 $\mu \mathrm{m}$ で実験した. 2 枚の基板で, 蒸着方向を反平行に組合せた.

\section{2 液 晶}

実験に使った液晶は CS-1011（チッソ）である. 図 2 に液晶の相系列を，表 1 に基礎的な物性定数を示 す.

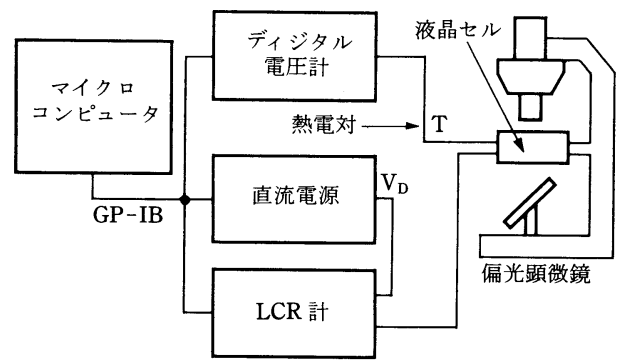

（a）偏光顕微鏡観察と静電容量の測定

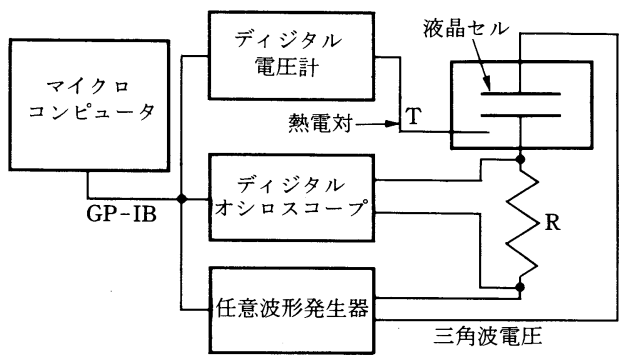

（b）自発分極の測定

図 3 配向状態の観察方法

Observation systems of molecular alignment.

(a) Observation by a polarization microscope and measurement of cell capacitance, (b) Measurement of spontaneous polalization.

\section{3 電界印加冷却処理}

まず液晶を等方性液体の状態まで加熱してセルに注 入した．次にセルを恒温槽の中に移し，電界を加えな がら $\mathrm{I}_{\mathrm{so}}$ 相から $35^{\circ} \mathrm{C}\left(\mathrm{S}_{\mathrm{c}}{ }^{*}\right.$ 相) まで降温した. 冷却中に 加えた電界は直流または交流(対称方形波) である. 電 界強度は, 直流については $2 \sim 22 \mathrm{MV} / \mathrm{m}$, 交流では $1 \sim 11 \mathrm{MV} / \mathrm{m}$ の範囲で実験した。なお特に断らない 限り, 交流電界の強度は実効值で表示する. 方形波の 周波数は $0.1 \mathrm{~Hz} \sim 1 \mathrm{kHz}$ の範囲で, また降温速度は $0.2 \sim 0.5^{\circ} \mathrm{C} / \mathrm{min}$ で実験した。

\section{4 配向状態の観察}

偏光顕微鏡で 観察するとともに, 静電容量と自発分 極の測定によって液晶の配向状態とスメクチック層の 傾斜を調べた．図 $3(a)$ ，（b ）に観察と測定に使った 装置の概略を示す.

\section{（1）偏光顕微鏡観察}

$\mathrm{Sc}_{\mathrm{c}}{ }^{*}$ 相まで冷却し，印加されていた電界を取り去っ たあと，液晶の初期配向を偏光顕微鏡で観察した。ま た，コノスコープ像から分子長軸の傾斜角や方位角を 調べた，傾斜角が大きい一部のセルについては，顕微 鏡にユニバーサルステージを取り付け，セルを傾けて コノスコープ像を調べた。さらに，冷却中に配向状態 
が変化する様子も顕微鏡観察した．特に $\mathrm{S}_{\mathrm{A}}$ 相におい ては液晶分子の長軸方向がスメクチック層の法線方向 と一致する.そこで, $\mathrm{S}_{\mathrm{A}}$ 相での分子配向状態に基づ いて, スメクチック層法線の傾斜角度や傾斜の方位角 を調べた．顕微鏡観察では, 降温速度は $1 \sim 2.5^{\circ} \mathrm{C} /$ minであった。

（2）静電容量の測定

直流電界を加えて冷却しながらセルの静電容量 $C$ を測定し, その変化から液晶分子の配向が変わる様子 を調べた。測定には LCR 計 $4274 \mathrm{~A}$ (YHP 社製) を使 った. 配向処理用の直流電圧と共に, $C$ の測定用と して $200 \mathrm{~Hz}$ で $0.5 \mathrm{~V}_{\mathrm{rms}}$ の正弦波電圧を加えた。なお $C$ はセル厚 $d$ と電極面積 $S$ で変わる. そこで, 次式

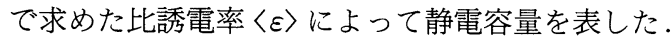

$$
\langle\varepsilon\rangle=(C \cdot d) /\left(\varepsilon_{0} \cdot S\right)
$$

ただし， $\varepsilon_{0}$ は真空の誘電率である.

\section{（3）自発分極の測定}

電極表面におけるスメクチック層法線の傾斜角 $\Psi$ を求めるため, 電界印加冷却が終わった後で三角波電

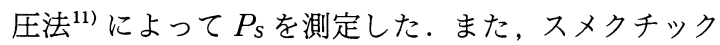
層が電極表面に対して垂直に形成されたセルを使い, $P_{S}$ の標準值 $P_{S 0}$ を測定した. 次に $P_{S}$ の值から $\Psi$ を 求める方法を説明する。 まず，層法線に対する FLC 分子の傾斜角 $\theta$ に比べて $\Psi$ が大きいセルを考える. この場合には, 充分高い電界を加えても $P_{S}$ は電界方 向と平行にならない.このため, 図 4 で示すように, 電極表面に垂直な方向への自発分極の成分が実効的な 自発分極 $P_{S E}$ として測定される ${ }^{8)}$.一方， $\Psi$ が小さく てスメクチック層が電極表面に対して垂直に近いと, 自発分極は電界と平行な状態まで回転できる．P $P_{S E}$ と $P_{S 0}$ との関係から， $\Psi$ は次式で表される.

$$
\Psi=\cos ^{-1}\left(P_{S 0} / P_{S E}\right)
$$

ただし, 得られた值はスメクチック層の傾斜角を電 極間全体について平均化した值を表すと考えられる。
$P_{S 0}$ の測定には, ポリアクリルニトリルの薄膜を付け てラビング処理したセルを使った．このセルでは FLC 分子が電極表面と平行に配向しており, $P_{s 0}$ は $15 \mathrm{nC} / \mathrm{cm}^{2}$ であった。 な押，セルに加えた三角波電界 の最大值は約 $10 \mathrm{MV} / \mathrm{m}$ であり, 測定はすべて $35^{\circ} \mathrm{C}$ で行った.

\section{3. 金属酸化物の蒸着処理による配向}

蒸着角度 $\omega$ を変えることによって分子配向がどの ように変わったかを述べる. 蒸着した 3 種類の材料に ついて配向状態に違いは見られなかった，以下では $\mathrm{Y}_{2} \mathrm{O}_{3}$ を用いて得られた結果を示す.

\section{$3.10^{\circ}$ 蒸着}

$\mathrm{N}^{*}$ 相と $\mathrm{S}_{\mathrm{A}}$ 相では, 分子長軸が基板法線からわず かに(約 $5^{\circ}$ ) 傾斜した垂直配向の状態が観察された。 ただし傾斜の方位は一定ではなかった． $\mathrm{S}_{\mathrm{c}}$ *相では， 写真 1 に示したようなドメインが現れ, セルを回転す るとドメインの明暗は変化した，視野を小さく絞って コノスコープ像を調べると, $\mathrm{S}_{\mathrm{c}}$ *では分子長軸が基板

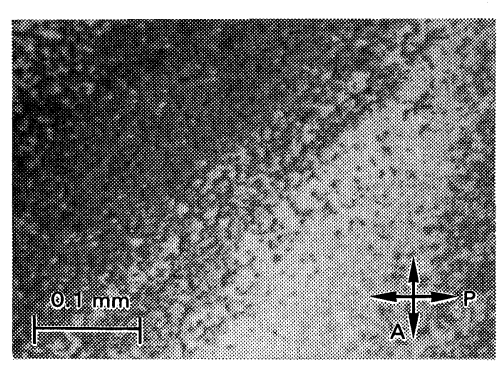

写真 $1 \mathrm{Y}_{2} \mathrm{O}_{3}$ を $0^{\circ}$ 蒸着処理したセスでの配向状態 (セル厚 : $1.5 \mu \mathrm{m}$. 液晶相: $\mathrm{Sc}^{*}$ )

Micrograph showing molecular alignment in the FLC cell with the $\mathrm{Y}_{2} \mathrm{O}_{3}$ film deposited at $0^{\circ}$ angle of incidence. (Cell thickness: $1.5 \mu \mathrm{m}$, liquid crystal phase: $\mathrm{Sc}_{\mathrm{c}}{ }^{*}$.)

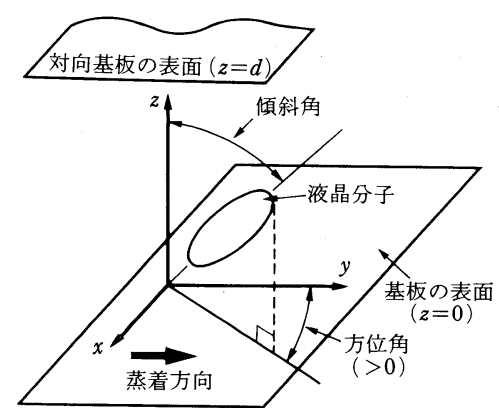

図 5 分子配向を表す座標系 A cooridanate system used to express tilt and azimuth angles of the aligned FLC molecules. 


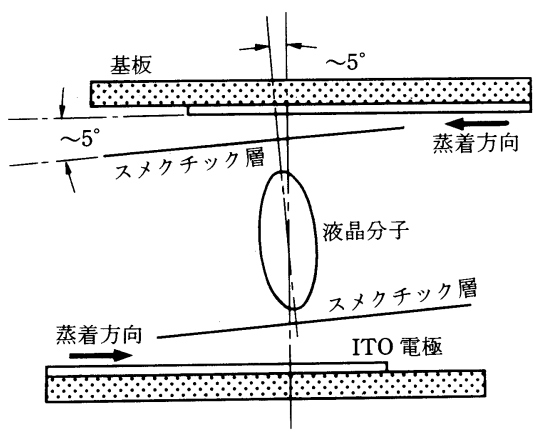

(a) $\mathrm{A}$ 型配向 $\left(\omega: 40^{\circ} \sim 60^{\circ}\right)$

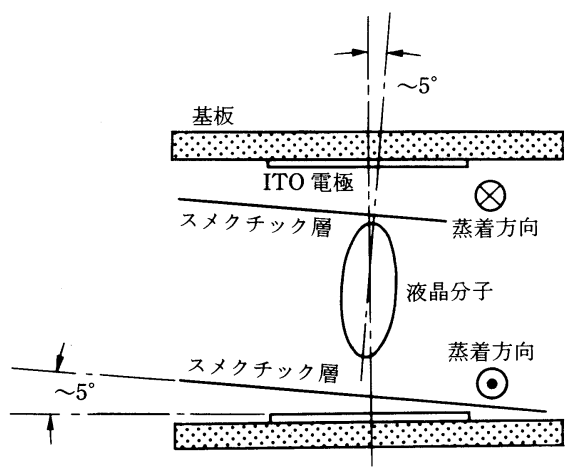

(b ) $\mathrm{B}$ 型配向 $\left(\omega: 60^{\circ}\right)$

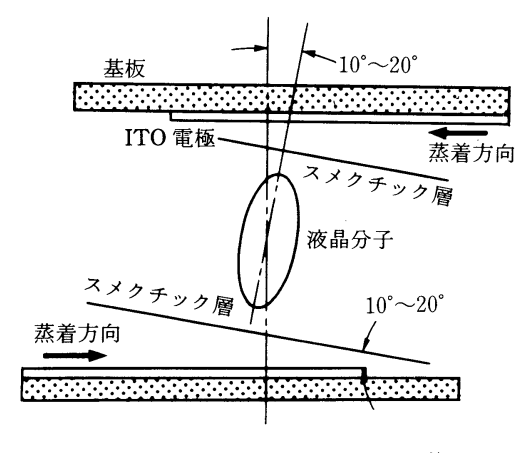

(c) $\mathrm{C}$ 型配向 $\left(\omega: 70^{\circ}, 80^{\circ}\right)$

図 $6 \mathrm{Y}_{2} \mathrm{O}_{3}$ を斜方蒸着したセルにおいて， $\mathrm{S}_{\mathrm{A}}$ 相で観 察された 3 種類の配向

The three types of molecular alignment in the $S_{A}$ phase which were observed on the obliquely deposited $\mathrm{Y}_{2} \mathrm{O}_{3}$ films.

(a) Type A $\left(\omega: 40^{\circ} \sim 60^{\circ}\right)$, ( b ) Type B $\left(\omega: 60^{\circ}\right)$,

(c) Type C $\left(\omega: 70^{\circ}, 80^{\circ}\right)$.

法線に対して約 $15^{\circ}$ 傾斜していることがわかった。た だし，セルを回転してドメインの明暗が変わったこと から，ドメインごとに分子長軸の傾斜の方位が異なっ ていると考えられる。

\section{2 斜方蒸着}

$\omega$ によって分子長軸の傾斜方位および傾斜角度が変
表 $2 \mathrm{Y}_{2} \mathrm{O}_{3}$ 斜方蒸着膜の上で観察された分子配向

(液晶相: $\mathrm{S}_{\mathrm{c}}{ }^{*}$ )

Molecular alignent in the $\mathrm{S}_{\mathrm{C}}{ }^{*}$ phase on obliquely deposited $\mathrm{Y}_{2} \mathrm{O}_{3}$ film.

\begin{tabular}{|c|c|c|c|}
\hline \multirow[b]{2}{*}{ 配向の種類 } & \multirow[b]{2}{*}{$\begin{array}{c}\text { 蒸着角度 } \\
\omega\end{array}$} & \multicolumn{2}{|c|}{ 分子配向 } \\
\hline & & $\begin{array}{l}\text { 分子長軸の傾斜角 } \\
\text { (基板の表面法線 } \\
\text { から) }\end{array}$ & $\begin{array}{l}\text { 分子長軸の傾斜方 } \\
\text { 位角 } \\
\text { (蒸着方向から) }\end{array}$ \\
\hline A型 & $\begin{array}{l}40^{\circ} \\
50^{\circ} \\
60^{\circ}\end{array}$ & $15^{\circ} \sim 20^{\circ}$ & $\begin{array}{c}+30^{\circ} \sim+40^{\circ} \\
+30^{\circ} \sim+40^{\circ} \\
+10^{\circ}\end{array}$ \\
\hline B型 & $60^{\circ}$ & $15^{\circ} \sim 20^{\circ}$ & $+70^{\circ}$ \\
\hline C型 & $\begin{array}{l}70^{\circ} \\
80^{\circ}\end{array}$ & $20^{\circ} \sim 30^{\circ}$ & $\begin{array}{l}+5^{\circ} \\
+15^{\circ}\end{array}$ \\
\hline
\end{tabular}

わった。そこで， $\mathrm{S}_{\mathrm{A}}$ 相における分子長軸の傾斜方位 に基づいて, 配向状態を 3 種類に分類した，以下では 図 5 に示す直交座標系によって傾斜角と方位角を表 す．一方の基板表面を $z=0(x y$ 平面）とし，この基板 における蒸着方向に平行して $y$ 軸をとる. 対向基板 の表面は $z=d$ に対応する.この座標系において, 分 子長軸の傾斜角を $z$ 軸に対する極角によって表示す る. また方位角については, 蒸着方向を $0^{\circ}$ で示し, $z$ $>0$ の方向からセルを見たとして, 分子長軸が時計方 向に回転している場合を正の角度で表す． $\mathrm{S}_{\mathrm{A}}$ 相にお ける配向のモデルを図 6 に，また， $\mathrm{S}_{\mathrm{c}}{ }^{*}$ 相おいて観察 された配向状態を表 2 に示す. A 型配向は $40^{\circ} お$ よび $50^{\circ}$ 蒸着膜の上で見られた. $60^{\circ}$ 蒸着では, $\mathrm{A}$ 型と $\mathrm{B}$ 型配向の一方か, または, 両方のドメインが混在して

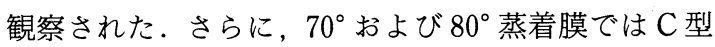
の配向状態が得られた。 $\omega$ が $40^{\circ} \sim 70^{\circ}$ の範囲では, スメクチック層法線の傾斜角度が小さく, スメクチッ ク層は基板表面に対して約 $5^{\circ}$ 傾斜したに過ぎなかっ た.一方, $80^{\circ}$ 蒸着セルでは, スメクチック層が基板 表面に対して約 $10^{\circ}$ 傾いて形成された。

電界に対する応答は, $80^{\circ}$ 蒸着セル以外では見られ なかった，すなわち， $\omega か ゙ ~ 40^{\circ} \sim 70^{\circ}$ の範囲において は, セルに駆動電圧を加えても分子配向の変形が小さ いかまたは起こらなかった。なお， $80^{\circ}$ 蒸着セルを駆 動した場合においても光透過度の変化は大きくなかっ た。

\section{4. 斜方蒸着と電界印加冷却によって 得られた配向}

ここでも, $\mathrm{Y}_{2} \mathrm{O}_{3}$ を蒸着材料に使って実験した結果 


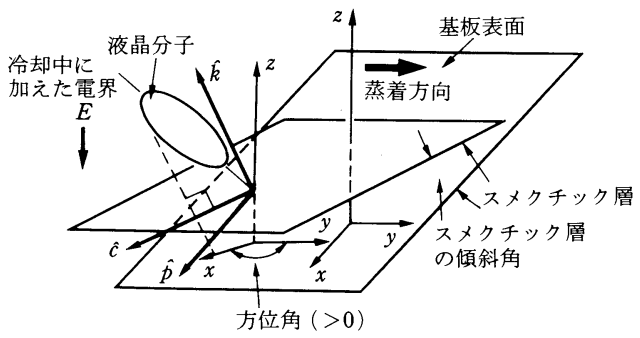

図 7 FLC 分子の方位と冷却中に加えた直流電界の 方向との関係

Relation between the azimuth of the long axis of the FLC molecule and direction of a DC electric field applied in the cooling process.

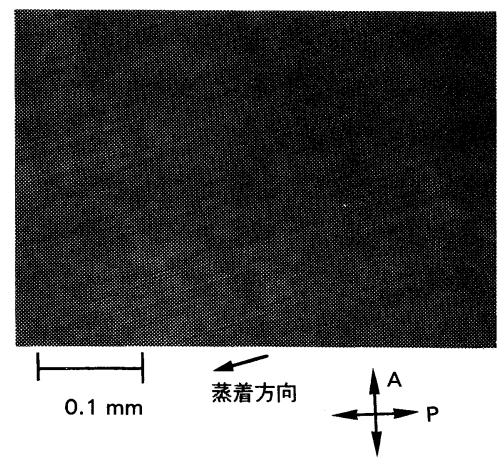

写真 $2 \mathrm{Y}_{2} \mathrm{O}_{3}$ の斜方蒸着と電界印加冷却処理とを組 合わせて得られた初期傾斜配向の一例 $(\omega$ : $60^{\circ}$, 冷却中に印加した電界: 直流 $20 \mathrm{MV} / \mathrm{m}$, セル厚 : $1.8 \mu \mathrm{m}$ )

An example of initially pretilted alignment in the $\mathrm{Sc}^{*}$ phase which was observed by the combined effects of $\mathrm{Y}_{2} \mathrm{O}_{3}$ oblique deposition and cooling process in an electric field. $\left(\omega: 60^{\circ}\right.$. Applied field in the cooling process: $\mathrm{DC}, 20 \mathrm{MV} / \mathrm{m}$. Cell thickness : $1.8 \mu \mathrm{m}$.)

を示す. 冷却中に加えた電界の周波数や強度によって 配向状態に違いが見られた。

\section{1 直流電界を加えた場合}

（1） $60^{\circ}$ 蒸着基板を使ったセル

冷却中に加える電界の強度を約 $5 \mathrm{MV} / \mathrm{m}$ 以上にし ておくと FLC 分子は一定の方位に傾斜し, 印加電界 を大きくすると傾斜角が大きくなった．例えば， 5 $\mathrm{MV} / \mathrm{m}$ の電界を加えたセルでは傾斜角が約 $30^{\circ}, 20$ $\mathrm{MV} / \mathrm{m}$ の電界を加えたものでは $50^{\circ}$ 程度であった。 方位角は電界強度によらず， $+160^{\circ} \sim+170^{\circ}$ または $+70^{\circ} \sim+80^{\circ}$ となった. 方位角が $90^{\circ}$ 異なる状態が観 察されていることは，3.2 節で述べたように， $60^{\circ}$ 蒸 着膜の上で $\mathrm{A}$ 型と $\mathrm{B}$ 型の 2 種類の配向状態が見られ たことに対応している. 方位角の符号と冷却中に加え
た電界の方向との間には図 7 に示す関係があった。こ こで, $\widehat{k}$ はスメクチック層の法線を表す単位べクト ル，历は自発分極の方向を示す単位べクトルである. また， $\hat{c}$ はカイラル・ダイレクター，すなわち，スメ クチック層面に対して FLC 分子の長軸を投影したも のを表すべクトルである．基本的には，PS 符号が 負であり，分子の傾斜方位は冷却中に加えておいた電 界の方向によって定まっている，これと逆方向に電界 を加えておいた場合には，方位角は $-160^{\circ} \sim-170^{\circ}$ または $+100^{\circ} \sim+110^{\circ}$ であった，写真 2 に，20 MV/ $\mathrm{m}$ の電界を加えて冷却処理したセルの初期配向を示 す.一様な配向が得られているが, 蒸着方向に沿って 周期的な縞が現れた. 冷却中に $5 \mathrm{MV} / \mathrm{m}$ 以上の直流 電界を加えたすべてのセルにおいて，このような縞が 観察された。縞が発生する機構はまだわかっていな い.

$5 \mathrm{MV} / \mathrm{m}$ 以下の電界を冷却中に加えたセルでは, 傾斜配向した領域とツイスト配向の領域が混在する か，またはツイスト配向の領域だけが観察された。

（2） $70^{\circ}$ 蒸着基板を使ったセル

基本的には，（1）で述べた $60^{\circ}$ 蒸着と電界印加冷却 で処理したセルと同様な傾斜配向が観察された. 分子 長軸の方位角は電界の方向によって決まっており， $+160^{\circ} \sim+170^{\circ}$ または $-160^{\circ} \sim-170^{\circ}$ となった。ま た，冷却中に加えた電界の強度を $5 \mathrm{MV} / \mathrm{m}$ 以上にす ると, 蒸着方向に沿った縞も現れた。

（3） $50^{\circ}$ 蒸着基板を使ったセル

印加していた電界の方向に応じて, 分子長軸の方位 角が $+10^{\circ} \sim+20^{\circ}$ または $-10^{\circ} \sim-20^{\circ}$ となった。傾 斜角の大きさや縞の発生については $60^{\circ} お$ おび $70^{\circ}$ 蒸 着と変わらなかった。

\section{2 交流電界を加えた場合}

$60^{\circ}$ 蒸着基板で構成したセルを使って実験した。電 界強度や周波数を変えることによって，3 種類の配向 が観察された。

\section{（1）傾斜配向}

数十 $\mathrm{Hz} \sim 1 \mathrm{kHz}$ の周波数で, 電界強度が約 $5 \mathrm{MV} /$ $\mathrm{m}$ を越えていると, FLC 分子は一定の方位に傾斜配 向した，方位角は $+160^{\circ} \sim+170^{\circ}$ または $+70^{\circ}$ 〜+80となった．方位角がほぼ一定となった理由は わかっていない，傾斜角については直流印加セルと同 様な值が得られた，例えば，100 Hzで $10 \mathrm{MV} / \mathrm{m}$ の 電界を加えて冷却した場合には，基板表面の法線に対 して分子が約 $45^{\circ}$ 傾斜した。 また，印加電界の強度が 5〜 $6 \mathrm{MV} / \mathrm{m}$ 以上であると, 一定の間隔をもち蒸着方 向に伸びた縞が観察された。これは, $5 \mathrm{MV} / \mathrm{m}$ 以上 


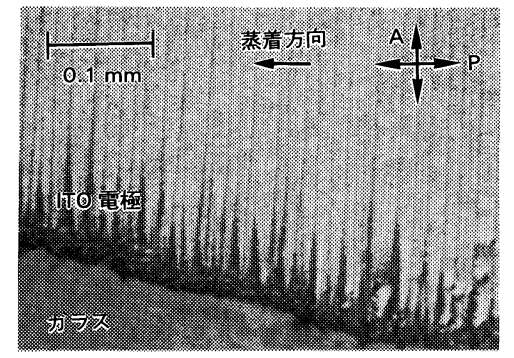

写真 $3 \quad \mathrm{Y}_{2} \mathrm{O}_{3}$ の斜方蒸着処理と電界印加冷却とを組 合わせて得られたツイスト配向 $\left(\omega: 60^{\circ}\right.$, 冷 却中に印加した電界: $100 \mathrm{~Hz}$, 対称方形波, 3 . $5 \mathrm{MV} / \mathrm{m}$, セル厚 : $3.2 \mu \mathrm{m}$ )

Twisted alignment in the $\mathrm{S}_{\mathrm{c}}{ }^{*}$ phase which was obtained by the effects of $\mathrm{Y}_{2} \mathrm{O}_{3}$ oblique deposition and cooling process in an AC electric field. ( $\omega: 60^{\circ}$, Applied field in the cooling process : $100 \mathrm{~Hz}$, square wave, $3.5 \mathrm{MV} / \mathrm{m}$. Cell thickness : $3.2 \mu \mathrm{m}$.)

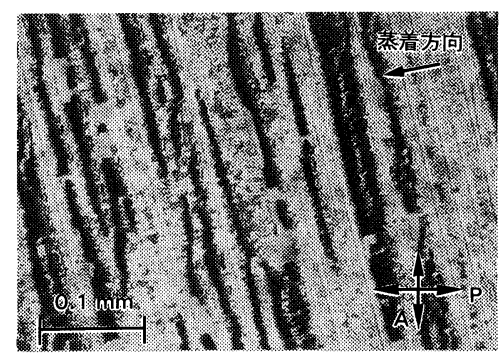

写真 4 傾斜配向とツイスト配向領域との混在(表面 処理: $\mathrm{Y}_{2} \mathrm{O}_{3} 60^{\circ}$ 蒸着. 冷却中に加えた電界： $10 \mathrm{~Hz}$, 対称方形波, $4.5 \mathrm{MV} / \mathrm{m}$. 七ル厚： $1.7 \mu \mathrm{m})$

Mixed alignment of twisted and tilted domains by the cooling process in an AC electric field. Surface treatment: deposition of $\mathrm{Y}_{2} \mathrm{O}_{3}$ at $60^{\circ}$ incidence. (Applied field in the cooling process : $10 \mathrm{~Hz}$, square wave, $4.5 \mathrm{MV} / \mathrm{m}$. Cell thickness : $1.7 \mu \mathrm{m}$.)

の直流電界を加えて冷却したセルで見られたものと同 じ縞である。

\section{(2) ツイス卜配向}

3〜 $5 \mathrm{MV} / \mathrm{m}$ の強度で, 数十 $\mathrm{Hz} \sim 1 \mathrm{kHz}$ の電界を 加えた場合には，液晶はツイスト配向した。 $100 \mathrm{~Hz}$, $3.5 \mathrm{MV} / \mathrm{m}$ の電界を加えて得られたツイスト配向を 写真 3 に示す．このセルの電極上には, スメクチック 層の方向，すなわち，蒸着方向と直交して縞が現れて いる. 縞の間隔は均一ではない. 縞は電極端に発生し たジグザグ欠陥に続いており，縞と配向欠陥との間に 何かの関係があると考えられる。このような縞が発生 する機構について充分な検討はできていない，ひとつ の可能性として，スメクチック層の傾斜が局部的に変 化して，層の方向に沿ってディスロケーションが発生

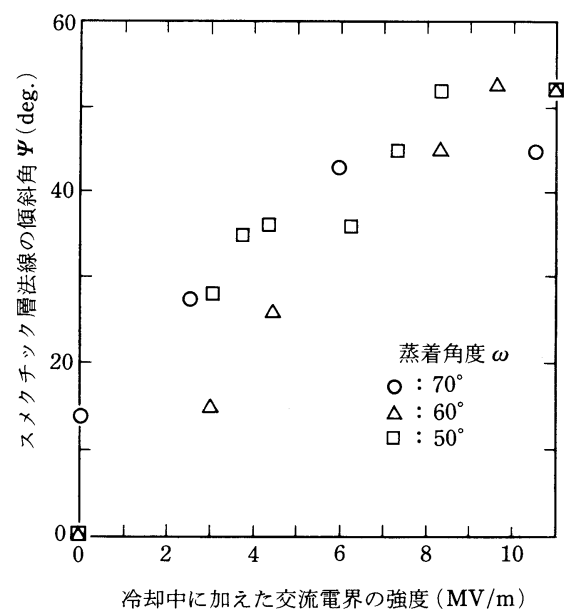

図 8 スメクチック層法線の傾斜角 $\Psi$ と冷却中に加 えた電界の強度との関係（基板の表面処理： $\mathrm{Y}_{2} \mathrm{O}_{3}$ の $60^{\circ}$ 蒸着, 冷却処理中に印加した電界: $100 \mathrm{~Hz}$ ，対称方形波)

Relation between tilt angle of the smectic layer normal $(\Psi)$ and strength of the electric field which was applied in the cooling process. (Surface treatment: deposition of $\mathrm{Y}_{2} \mathrm{O}_{3}$ at $60^{\circ}$ incidence. Applied field in the cooling process : $100 \mathrm{~Hz}$, square wave.)

しているのではないかと考えられている12)。なお，縞 の発生を伴わずにツイスト配向したセルも観察され た。

（3）傾斜配向とツイスト配向との混在

周波数を数 $\mathrm{Hz}$ 以下に下げると, 傾斜配向の領域と ツイスト配向領域とが混在した。このような配向状態 の一例を写真 4 に示す. $10 \mathrm{~Hz}, 4.5 \mathrm{MV} / \mathrm{m}$ の電界を 冷却中に加えた。蒸着方向と直交した縞が現れ，傾斜 配向した領域とツイスト配向領域とが縞に沿って広が つた.

\section{3 スメクチック層法線の傾斜角}

図 8 は, スメクチック層法線の傾斜角 $\Psi$ を測定し た結果である. $100 \mathrm{~Hz}$ の交流電界を冷却中に加え， この電界強度によって $\Psi$ がどのように変わったかを 調べた，電界を強くすると $\Psi$ は大きくなるが，どの 蒸着角度に扔いても約 $6 \mathrm{MV} / \mathrm{m}$ 以上の強度で, $\Psi$ は $45^{\circ} \sim 50^{\circ}$ となって飽和している.

\section{5. 電界印加冷却の途中における配向の変化}

電界印加冷却の過程で配向状態がどのように変化し たかを述べる．ここでは，蒸着材料が $\mathrm{Y}_{2} \mathrm{O}_{3}, \omega$ が $60^{\circ}$ という条件で実験した。この観察では， $20 \mathrm{MV} / \mathrm{m}$ の 直流電界を加えて冷却し, 偏光顕微鏡観察に加えて, 冷却が進むに伴ってセルの静電容量がどのように変わ 


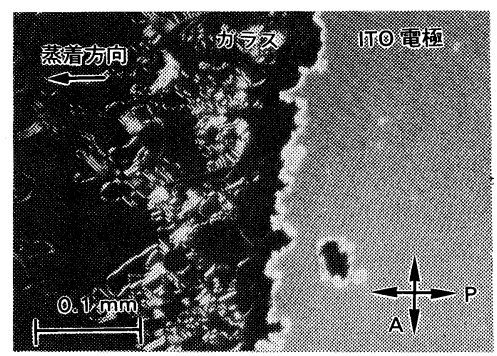

(a) $\mathrm{N}^{*}$ 相 $\left(76^{\circ} \mathrm{C}\right)$

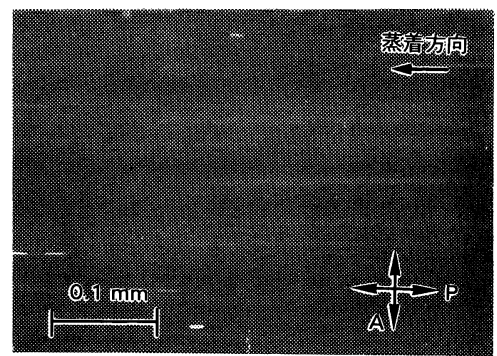

(b) $\mathrm{S}_{\mathrm{A}}$ 相 $\left(55^{\circ} \mathrm{C}\right)$

写真 5 電界印加冷却中の配向状態の変化（基板の表 面処理: $\mathrm{Y}_{2} \mathrm{O}_{3} 60^{\circ}$ 蒸着. 印加電界 : 直流, 15 $\mathrm{MV} / \mathrm{m}$. セル厚 : $1.8 \mu \mathrm{m}$ )

Micrographs showing changes in molecular alignment in the cooling process in an electric field. (Surface treatment: deposition of $\mathrm{Y}_{2} \mathrm{O}_{3}$ at $60^{\circ}$ incidence. Applied field in the cooling process: DC, $15 \mathrm{MV} / \mathrm{m}$. Cell thickness : $1.8 \mu \mathrm{m}$.) (a ) $\mathrm{N}^{*}$ phase $(76$ $\left.{ }^{\circ} \mathrm{C}\right)$. (b) $\mathrm{S}_{\mathrm{A}}$ phase $\left(55^{\circ} \mathrm{C}\right)$.

\section{るかを測定した。}

\section{$5.1 \mathrm{~N}^{*}$ 相での配向}

写真 5(a) は $\mathrm{N}^{*}$ 相での配向状態を示す. 電極上で は青い光が一様に透過し, 電極部分は明るく観察され た.コノスコープ観察ではアイソジャイヤーが見られ なかった．さらに，セルを回転して入射光の偏光方向 を変えたり, または, 偏光板の偏光方向を直交から平 行の位置まで動かしても，電極部分の透過光強度には 大きい変化が観察されなかった。一方, 電極の外部に は, 垂直配向した領域と共に, $\mathrm{N}^{*}$ 相に特有なフィン ガープリントまたはスクロール組織が現れていた。し たがって，これらの組織が観察された領域では，らせ ん構造を持つ配向状態になっていると考えられる. 写 真 5 (a)では, らせん構造が解けて, 液晶分子が垂直 配向したため暗い領域が広がっている。一方, 電極上 の分子配向にも，らせん構造ができていると考えられ る.ただし, 電界が加えられているので, らせん構造 は変形を受けているであろう．特に，実験に使った液 晶が負の常誘電異方性を持つため, らせん軸は基板表 面に対して傾斜しているものと考えられる．

\section{$5.2 \mathrm{~S}_{\mathrm{A}}$ 相における配向}

$\mathrm{S}_{\mathrm{A}}$ 相に転移したあと，電極上で見られた配向状態 を写真 5 (b) に示す.コノスコープ観察から，このセ ルでは分子の長軸が蒸着方向に傾いており, 傾斜角度 は基板法線に対して $25^{\circ} \sim 30^{\circ}$ であることがわかった． また傾斜の方位が蒸着方向と直交したセルもあった．

$\mathrm{S}_{\mathrm{A}}$ 相では液晶分子の長軸がスメクチック層の法線 方向を向いている．したがって，電極上でスメクチッ ク層は基板表面から $25^{\circ} \sim 30^{\circ}$ 傾いて形成されたこと になる．1つのセル内で, 層法線の傾斜方位は蒸着方 向に対して平行かまたは垂直のどちらか一方であっ た。

さらに，写真 $5(\mathrm{~b})$ でも見られるように，薄い縞が 蒸着方向に現れた。なお, 縞は電極上だけに発生し た。

\section{$5.3 \mathrm{Sc}^{*}$ 相での配向}

室温まで降温した後，冷却中に加えていた電界を取 り去ると, 電極上では写真 2 に示す初期配向状態が観 察された。コノスコープ像から, 分子長軸の傾斜角度 が $45^{\circ}$ 程度まで大きくなったことがわかり，傾斜の方 位は $+170^{\circ}$ であった。

観察したすべてのセルにおいて，電極上で分子長軸 の傾斜角度は $45^{\circ}$ 程度になった。また，分子の傾斜方 位は $\mathrm{S}_{\mathrm{A}}$ 相における傾斜方位から $10^{\circ} \sim 20^{\circ}$ ずれてい た. $\mathrm{S}_{\mathrm{A}}$ 相から $\mathrm{S}_{\mathrm{c}}$ * 相への相転移に伴って，スメクチ ック層の傾斜角度や傾斜の方位が変化したかどうかは 顕微鏡観察だけではわからない，基本的には，傾斜角 度の増加や傾斜方位のずれは， $\mathrm{Sc}^{*}$ 相に転移すると層 法線に対して分子が傾斜する性質によるものと考えら れる。

蒸着方向に伸びた縞は $\mathrm{S}_{\mathrm{c}}{ }^{*}$ 相でも観察された．縞の 周期は $3 \mu \mathrm{m}$ 前後であった。なお， $\mathrm{S}_{\mathrm{A}}$ 相にあった時と 比べて, $\mathrm{S}_{\mathrm{C}}$ * 相では縞がはっきり見えるようになっ た。

\section{4 冷却中の静電容量の変化}

セルの静電容量が冷却の途中で変化する様子を図 9 に示す．この実験では 1 個のセルを使い, 冷却中に加 える直流電界の強度を変えて測定を行った。

Iso 相では，電界を加えて冷却すると静電容量が小 さくなった．詳しい機構については検討が必要である が，等方性液体中の分極電荷が直流バイアス電界によ って固定され, $200 \mathrm{~Hz}$ の交流電圧に応じて流れる変 位電流が減少して静電容量が小さくなったことが考え られる。

$\mathrm{N}^{*}$ 相から $\mathrm{S}_{\mathrm{A}}$ へ人ると, 加えている電界の強度が 大きいと静電容量も大きくなった。これらの相ではセ 


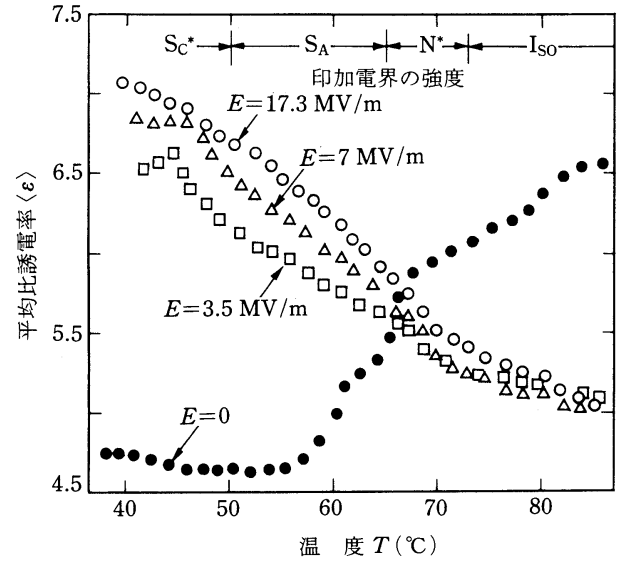

図 9 直流電界を加えた冷却処理中の静電容量の変化 (表面処理: $\mathrm{Y}_{2} \mathrm{O}_{3} 60^{\circ}$ 蒸着, セル厚 : $2.9 \mu \mathrm{m}$ ) Variation of the cell capacitance in the cooling process with DC electric field. (Cell thikness: $2.9 \mu \mathrm{m}$.

ルの静電容量が誘電分極の大きさによって定まる．実 験に使った液晶の常誘電異方性は負である。このた め, 高電界を加えると液晶分子の長軸方向が電極表面 と平行に近づき, セルの静電容量は大きくなると考え られる. $\mathrm{Y}_{2} \mathrm{O}_{3}$ 蒸着膜だけの配向効果では, スメクチ ック層が電極表面と平行かまたは小さく傾斜して形成 される。すなわち, 層法線の傾斜角度 $\Psi$ が $90^{\circ}$ に近 い.しかし，冷却中に充分高い電界を加えておけば $\Psi$ は小さくなる。これは 4.3 節で示した $\Psi$ の測定結 果と対応している。したがって, 液晶の常誘電異方性 が負であったため, 電界印加冷却処理によって $\Psi$ が 小さくなったと考えられる。

$\mathrm{S}^{*}$ 相に転移した後も, 冷却電界が高いほど静電容 量は大きくなった． $\mathrm{Sc}^{*}$ 相になると，七ルの静電容量 は誘電分極による成分と自発分極 $\left(\mathrm{P}_{\mathrm{S}}\right)$ による成分を

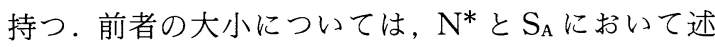
べたことと全く同じ説明ができる，一方，後者の大き さは, $P_{s}$ の回転に伴って電極上に誘起される電荷量 の変化に相当し, Ps が大きいほど静電容量も大きく なると考えられる. 2.4 節で示したように，スメクチ ック層が電極表面に対して垂直に近いほど実効的な $\mathrm{P}_{\mathrm{s}}$ は大きい。したがって, $\mathrm{S}_{\mathrm{c}}$ *相においても $\Psi$ が小 さくなるとセルの静電容量は大きくなる.

\section{6. セル全体での分子配向}

\section{1 電極内外における分子配向の違いの影響}

セルの電極上では, 電界印加冷却による配向効果が 液晶に作用し, 電極の外では斜方蒸着膜の配向効果が 作用する．このため, 電極端においてスメクチック層
の傾斜角度や層法線の方位角に食い違いができる．例 えば，写真 3 に配向状態を示したセルでは, 電極の内 外に扔いて, 層法線の方位角は蒸着方向に対して $90^{\circ}$ で変わらなかった。一方, 基板表面に対するスメクチ

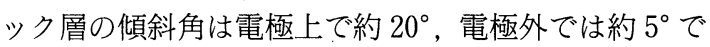
あった．このセルの電極端にはジグザグ欠陥が見られ た.また，電極の内外で層の傾斜角と層法線の方位角 が共に大きく変化する場合には，フォーカルコニック 型のドメインが電極の周囲に現れた ${ }^{10)}$. しかし肉眼観 察では，これらのドメインが表示を損なうことはなか つた。

\section{2 電極外部の無彩色化}

電極外部では, 基板の表面法線に対する FLC 分子 の傾斜角が小さく，したがって複屈折も小さくなって いる.このため, 波長分散の小さな偏光板と組合せれ ば表示電極の背景を無彩色化することができるものと 期待される。一方, ラビング処理によってツイスト配 向したセルでは, 電極外部での着色が問題になる. $\mathrm{SS}$ 型セルではセル厚 $d$ を液晶のカイラルピッチに比 べて小さくすることが必要であり ${ }^{1)}$, 現在までに開発 された FLCにおいては， $d$ が $2 \sim 3 \mu \mathrm{m}$ 以下に制限さ れている.このような薄いセルでは液晶分子がツイス 卜配向すると，モーガン条件 ${ }^{13)}$,

$$
d \cdot \Delta n \gg(\lambda / 2)
$$

が成立しなくなる。ここで, $\Delta n$ は液晶の複屈折の大 きさ，入は入射光の波長を表す，モーガン条件が満足 されていないと, 入射した直線偏光が液晶を通る間に 楕円偏光に変わる ${ }^{14)}$.このため, 表示電極の背景では 特定の干渉色が観察され, 暗状態が見られない.さら に, SS 型の平行配向セルにおいては, 現状では $d$ が 小さな值に制限されているためレターデーション $(d \cdot \Delta n)$ も小さく, 干渉色が観察されないものもあ る.しかし， $d$ が小さいと表示素子の大型化に伴って パネル厚の制御は難しくなる。このため, 大型パネル ではカイラルピッチの長い FLCを使って $d$ への制限 を緩めることが必要になるであろう，ただし，平行配 向ではパネルが厚くなるとレターデーションによる着 色が起きてくる．したがって, 表示電極の背景を無彩 色化しやすいという点については, 垂直配向の方がツ イストまたは平行配向に比べて有利だと考えられる。

\section{7. むす び}

$\mathrm{Y}_{2} \mathrm{O}_{3}, \mathrm{Sm}_{2} \mathrm{O}_{3}, \mathrm{Al}_{2} \mathrm{O}_{3}$ の斜方蒸着処理および斜方蒸着 と電界印加冷却との組合せによって FLCの配向を調 べた，次に示す実験結果が得られた。

（1）斜方蒸着処理によってスメクチック層が基板 
に対して傾き，FLC 分子は傾斜配向した。た だし，スメクチック層の傾斜角度は小さく，蒸 着角が $40^{\circ} \sim 70^{\circ}$ の範囲では基板表面に対して 約 $5^{\circ}, 80^{\circ}$ 蒸着基板においても $20^{\circ}$ 程度であっ た.また，分子長軸の傾斜角も大きくなく，基 板の表面法線に対して $15^{\circ} \sim 30^{\circ}$ であった.

（2） $40^{\circ}$ または $50^{\circ}$ 蒸着処理と $70^{\circ}$ または $80^{\circ}$ 蒸 着処理とでは, $\mathrm{S}_{\mathrm{A}}$ 相における FLC 分子長軸の 傾斜方位，したがって，スメクチック層法線の 傾斜方位が反転した。

（3）冷却中に $5 \mathrm{MV} / \mathrm{m}$ 以上の強度で直流または 数十 $\mathrm{Hz} \sim 1 \mathrm{kHz}$ の交流電界を加えると，スメ クチック層法線の傾斜角と FLC 分子長軸の傾 斜角が共に大きくなった． $50^{\circ} \sim 70^{\circ}$ 蒸着膜の上 においても，10 MV/m の方形波電界を冷却中 に加えておくと，スメクチック層法線の傾斜角 は $45^{\circ}$ 程度まで増加した。

（4）冷却中にセルの静電容量を測定した実験結果 から，加える電界の強度が大きいほど $\mathrm{S}_{\mathrm{A}}$ 相に おいて静電容量も大きくなることがわかつた． 使った FLCの常誘電異方性が負であったた め, 印加電界によって分子の傾斜が大きくなっ たものと考えられる

（5）斜方蒸着膜だけの配向効果では，分子長軸の 傾斜角は大きくない。このため，パネルを適当 な中性偏光板と組合せれば，表示電極の背景を 無彩色化することができる。

今後, セルの特性を詳しく調べ, マトリックスパネ ルへの応用についても検討する予定である．

(昭和 63 年 3 月 28 日受付, 昭和 63 年 7 月 14 日再受付)

\section{〔参 考 文 献〕}

1) N. A. Clark and S. T. Lagerwall: "Submicrosecond Bistable Electro-optic Switching in Liquid Crystals", Appl. Phys. Lett., 36, 11, pp. 899-901 (June, 1980)

2）田中, 木越, 関川, 清水, 堀: “強誘電性液晶の配向の安定化の 試み”, 第 34 回応物春季予縞集, 30 p-D-13, p. 617(1987)

3) S. Shimoda, K. Ito, T. Harada, M. Taguchi, K. Iwasa and M. Kai : "Optimum Bias Condition for Multiplex Driving of the Chiral Smectic C LCD”, Proc. 6th Int. Display Res. Conf., pp. $460-462(1986)$

4）鎌上, 村山, 羽藤, 松本：“強誘電性液晶素子のマルチプレッ クス駆動特性”, 第 12 回液晶討論会予稿集, pp. 88-89(1986)

5) J. S. Patel, T. M. Leslie and J. W. Goodby: "A Reliable Method of Alignment for Smectic Liquid Crystals", Fer- roelectrics, 59, 1-2, pp. 137-144(1984)

6) 南, 高橋, 桑原, 女川, 宮下: “強誘電性液晶の電界誘起変形”, 第 10 回液晶討論会予稿集, pp. 122-123(1984)

7) T. Uemura, N. Ohba, N. Wakita, H. Ohnishi and I. Ota : "Alignment of Chiral Smectic C Liquid Crystal by Oblique Evaporation Method", Proc. 6th Int. Display Res. Conf., pp. 464-467 (1986)

8）廣嶋，清水：“ $\mathrm{SiO}$ 回転斜方蒸着膜の強誘電性液晶分子配向 特性”, 第 12 回液晶討論会予稿集, pp. 32-33(1986)

9）川田, 桑原, 女川, 宮下: “斜め蒸着処理と直流電界印加によ る強誘電性液晶の配向制御”, 第 34 回応物春季予稿集, $30 \mathrm{p}-$ D-8, p. 616(1987)

10）桑原，田代，女川，宮下：“強誘電性液晶の配向制御一斜方蒸 着と電界印加冷却による配向効果一”, 信学技報, $87,363, \mathrm{pp}$ 69-75(Feb., 1988)

11) K. Miyasato, S. Abe, H. Takezoe, A. Fukuda and E Kuze: "Direct Method with Triangular Waves for Measuring Spontaneous Polarization in Ferroelelctric Liquid Crystals", Jpn. J. Appl. Phys., 22, 10, pp. L661-L663 (1983)

12) Y.Sato, T. Tanaka, M. Nagata, H. Takeshita and S Morozumi: "Effects of an ac Field on the Orientation and the Contrast Ratio of Ferroelectric Liquid Crystals", Proc. 6th Int. Display Res. Conf., pp. 348-351 (1986)

13) G. Baur: "The Influence of Material and Device Parameters on the Optical Characteristics of Liquid Crystal Displays", Mol. Cryst. \& Liq. Cryst., 63, 1-4, pp. 45-58 (1981)

14) T. Shingu, T. Tuchiya, Y. Ouchi, H. Takezoe and A. Fu kuda: "Molecular Selective Pre-Tilt on Glass Surfaces and Color Difference between Two Twisted States in Surface Stabilized Ferroelectric Liquid Crystal Cells", Jpn. J. Appl. Phys., 25, 3, pp. L206-L208(Mar., 1986)

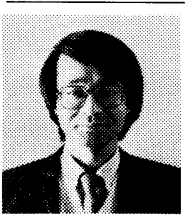

桑原 道夫势 昭和 47 年, 富山大学大学院 工学研究科修士課程修了. 同年, 富山大学工 学部電子工学科助手. 液晶表示素子, 液晶の 分子配向制御等の研究に従事.

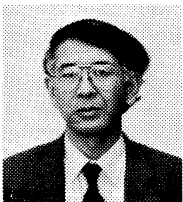

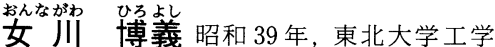
部電子工学科卒業. 同年, 東北大学工学部電 子工学科助手. 44 年, 富山大学工学部電子 工学科助手. 現在, 同教授. 熱電半導体, 液 晶素子，エレクトロクロミック素子、化合物 太陽電池, 薄膜エレクトロルミネッセンス素 子の研究に従事. 工学博士.

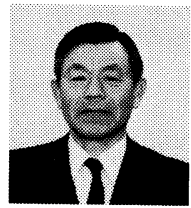

みやした 加ず

宮下和雄 昭和 36 年, 東北大学大学院 工学研究科博士課程修了. 同年, 東北大学工 学部電子工学科助手. 38 年, 同助教授. 43 年, 富山大工学部電子工学科教授. 62 年, 富山大学地域共同研究センター長併任. エレ クトロルミネッセンス素子, 液晶素子, 化合 物太陽電池等の研究に従事. 工学博士. 正会 員. 


\title{
Molecular Alignment Control in Ferroelectric Liquid Crystal Cells by Combined Effects of Oblique Deposition and Electric Field Application in the Cooling Process

\author{
by Michio Kuwahara, Hiroyoshi Onnagawa and Kazuo Miyashita
}

A method of controlling molecular alignment in ferroelectric smectic liquid crystal (FLC) cells is described. It uses the combined effects of the following two steps of treatment : (1) oblique deposition of metal oxide, e.g., yttrium oxide, to the substrate surface, and (2) application of an electric field in the process of cooling from the isotropic liquid of the FLC to its chiral smectic $C$ phase. With the combination of the deposition at $60^{\circ}$ incidence and the application of a DC field with a strength of about $10 \mathrm{MV} / \mathrm{m}$ in the cooling process, the FLC molecules are aligned to a uniform pretilt of about $50^{\circ}$. Smectic layers are inclined at $40^{\circ} \sim 50^{\circ}$ to the electrode surface in this cell. When no electric field is applied in the cooling process, on the other hand, the pretilt angle of the molecules is about $15^{\circ}$ and the smectic layers are nearly parallel to the substrate surface.

J.Inst. TV Engrs. of Japan, Vol. 42, No. 10 (1988) 1042 1050

\section{A Complex Lens Trinitron Gun for a High-Resolution Color Tube}

\author{
by Kouji Ichida, Yoshifumi Nakayama and Hiromu Inoue
}

$19 \mathrm{~V}^{\prime \prime}$ Cathode Ray Tubes (CTRs) with phosphor pitch of $0.31 \mathrm{~mm}$ and neck diameter of $36.5 \mathrm{~mm}$ have been installed in graphic display monitors with the $1280 \times 1024$ pixel format. However, to meet user demand for greater compactness, a new Trinitron gun has been developed for $16 \mathrm{~V}^{\prime \prime}$ high resolution CRT with neck diameter of $30.6 \mathrm{~mm}$. A combination of small caliber bi-potential and large caliber Trinitron lenses, complex lens structure, is employed for the new gun in order to obtain the same resolution as the current on $16 \mathrm{~V}^{\prime \prime} \mathrm{CRT}$ with $30.6 \mathrm{~mm}$ diameter. The spherical aberration coefficient has successfully been reduced by half with optimum gun structures calculated by the finite element method (FEM).

As a result, this gun's spot size at screen center is now as small as that of the conventional Trinitron gun for $36.5 \mathrm{~mm}$ neck. The spot size at the screen corner is also well-focused by dynamic focus and well-formed by dynamic electrical magnetic quadrupole.

J.Inst. TV Engrs. of Japan, Vol. 42, No. 10 (1988) 1051 1056

\section{Digital-Driven CRT Light Source for Hard-Copy Printers by Haruo Okuda, Makoto Tadenuma and Shin Ohno}

On a CRT hard-copy printer, normal analog modulation of the CRT light source does not produce optimum resolution, dynamic range, or tone reproduction on the output video hardcopies. Two new digital driving methods, pulse number and pulse width modulation for CRT emission, improve these pictorial characteristics. The former has superior linear relation of input and output when driving the CRT. Furthermore multiple pulse amplitude effectively shortens printing time. The dynamic range of emission expands sufficiently to expose the film, and the resolution doubles from that obtained by analog modulation.

The output video hard-copies prepared by $\mathrm{Hi}$-Vision signals are very impressive, equalling conventional photographic print quality. 